Int J Clin Exp Pathol 2012;5(1):29-36

www.ijcep.com /ISSN: 1936-2625/IJCEP1111001

\title{
Original Article Protective effect of xanthohumol on toxin-induced liver inflammation and fibrosis
}

\author{
Christoph Dorn¹, Jörg Heilmann², Claus Hellerbrand ${ }^{1}$ \\ ${ }^{1}$ Department of Internal Medicine I, University Hospital Regensburg, Germany; ${ }^{2}$ Institute of Pharmacy, University of \\ Regensburg, Germany
}

Received November 1, 2011; accepted December 6, 2011; Epub January 1, 2012; Published January 15, 2012

\begin{abstract}
Xanthohumol, the major prenylated chalcone found in hops, is known for its anti-inflammatory properties. We have recently shown that xanthohumol inhibits hepatic inflammation and fibrosis in a murine model of nonalcoholic steatohepatitis. The aim of this study was to investigate the effect of xanthohumol in an acute model of liver injury. Carbon tetrachloride $\left(\mathrm{CCl}_{4}\right)$, an industrial solvent, is a hepatotoxic agent and its administration is widely used as an animal model of toxin-induced liver injury. Xanthohumol was applied orally at a dose of $1 \mathrm{mg} / \mathrm{g}$ body weight 2 days prior as well as during and after exposure to $\mathrm{CCl}_{4} .72 \mathrm{~h}$ after a single $\mathrm{CCl}_{4}$ application histomorphology and serum levels of transaminases revealed considerable hepatocellular necrosis, which was accompanied by significantly enhanced hepatic expression of pro-inflammatory cytokines. Furthermore, elevated hepatic alpha-smooth muscle actin expression indicated activation of hepatic stellate cells, and in accordance, we detected enhanced hepatic expression levels of TGF- $\beta$ and collagen type I reflecting a marked fibrogenic response to $\mathrm{CCl}_{4}$ exposure. While the degree of hepatocellular damage in response to $\mathrm{CCl}_{4}$ was similar in mice which received xanthohumol and the control group, pro-inflammatory and profibrogenic hepatic gene expression were almost completely blunted in xanthohumol fed mice. Furthermore, xanthohumol fed mice revealed decreased hepatic NFkB activity. These results suggest that the protective effects of xanthohumol in this toxic liver injury model involves direct mechanisms related to its ability to block both hepatic inflammation and the activation of hepatic stellate cells, presumable at least in part via decreasing NFkB activity. Thus, this study further indicates the potential of xanthohumol application to prevent or ameliorate the development and progression of liver fibrosis in response to hepatic injury.
\end{abstract}

Keywords: Xanthohumol, carbon tetrachloride, fibrosis, inflammation, acute liver injury

\section{Introduction}

Xanthohumol $(\mathrm{XN})$ is the principal prenylated chalcone of the female inflorescences (hop cones, hops) of the hop plant Humulus lupulus L. and it has been shown to have several beneficial biological activities. Among them its chemopreventive and anti-inflammatory properties are the most extensively investigated [1, 2], and these are at least in part mediated via inhibition of the NFKB signaling pathway [3-6]. We have shown previously that $\mathrm{XN}$ inhibits hepatic inflammation and fibrosis in a murine model of non-alcoholic fatty liver disease (NAFLD) [6]. NAFLD is considered as the most frequent liver disease in Western countries [7-9]. It is characterized by hepatocellular lipid accumulation, on the ground of which inflammation and fibrosis may develop. The histological picture closely resembles alcoholic liver disease [10]. In nonalcoholic steatohepatitis (NASH) and alcoholic steatohepatitis (ASH) as well as in other chronic liver diseases like viral hepatitis, hepatic fibrosis is the peril that determines morbidity and mortality. Cirrhosis, as the end stage of hepatic fibrosis, is a major clinical issue for its high prevalence in the world and its tight relationship with hepatocellular carcinoma incidence [1113]. Hepatic fibrosis is characterized by an excessive and aberrant deposition of extracellular matrix (ECM) proteins in the liver, the most abundant of which is collagen type I [14]. Activated hepatic stellate cells (HSC) are the cellular source of the excessive ECM deposition [1517]. Normally, these cells are quiescent and produce only small amounts of ECM components, such as laminin and collagen type IV, during the formation of basement membrane 
[18]. However, in response to hepatic injury HSC get activated and transform into a myofibroblast -like phenotype, expressing alpha-smooth muscle actin ( $\alpha-S M A)$, and dramatically increase the production of collagens [19]. Importantly, the transcription factor NFKB plays a crucial role in HSC activation [20, 21, 15, 22].

In addition to metabolic overload, alcohol or viral infection the liver is frequently exposed to various insults, including toxic chemicals [23, 24]. Liver damage caused by hepatotoxic chemicals induces compensatory hepatic hyperplasia after severe liver necrosis due to direct damage of hepatocytes and subsequent inflammation [25]. Carbon tetrachloride $\left(\mathrm{CCl}_{4}\right)$, an industrial solvent, is a hepatotoxic agent and its administration is widely used as an animal model of toxin-induced liver injury that allows the evaluation of both necrosis and subsequent inflammation [26] as well as fibrosis [27]. In contrast to our previously used NASH-model which led to only mild hepatocellular damage and inflammation [6], $\mathrm{CCl}_{4}$ application results in excessive necrotic and apoptotic death of hepatocytes, which induces the activation of HSC.

To investigate the effect of $\mathrm{XN}$ on acute liver injury and to further study its role in liver fibrosis, we subjected mice, which were treated with and without $\mathrm{XN}$ at a dose of approximately 1 $\mathrm{mg} / \mathrm{g}$ body weight, to acute $\mathrm{CCl}_{4}$-induced liver damage.

\section{Methods}

\section{Chemicals and animal feeds}

Carbon tetrachloride $\left(\mathrm{CCl}_{4}\right)$ and olive oil were obtained from Sigma Pharmaceuticals (Hamburg, Germany). Xanthohumol (XN) was obtained from Alexis Biochemicals (Lausen, Switzerland) with a purity $\geq 98 \%$ determined by HPLC. All chows were prepared by Ssniff (Soest, Germany).

\section{$\mathrm{CCl}_{4}$-induced acute liver injury}

A single dose of $\mathrm{CCl}_{4}(1 \mu \mathrm{l} / \mathrm{g}$ body weight in olive oil) was intraperitoneally injected to 10 weeks old female BALB/c mice. $72 \mathrm{~h}$ after $\mathrm{CCl}_{4}$ injection, mice were killed by heart puncture under deep ketamine/xylazine $(2: 1)$ anesthesia, and liver tissue and blood samples were collected for further analysis. Livers and blood from olive oil treated animals served as controls.

\section{Histology}

For histological analysis murine liver tissue specimens were fixed for $24 \mathrm{~h}$ in $4 \%$ formalin at room temperature, dehydrated by graded ethanol and embedded in paraffin. Tissue sections (thickness $5 \mu \mathrm{m}$ ) were deparaffinized with $x y$ lene and stained with eosin/haematoxylin (H\&E) as described [28].

\section{Quantitative real time-PCR analysis}

RNA isolation from liver tissue and reverse transcription were performed as described [29]. Quantitative real time-PCR was performed applying LightCycler technology (Roche, Mannheim, Germany) as described [30] applying the following pairs of primers: murine collagen-I (for: 5'-CGG GCA GGA CTT GGG TA; rev: 5'-CGG AAT CTG AAT GGT CTG ACT) and murine MCP-1 (for: 5'-TGG GCC TGC TGT TCA CA; rev: 5'-TCC GAT CCA GGT TTT TAA TGT A). All other mRNA expression analyses were performed using QuantiTect Primer Assays according to the manufacturer's instructions (Qiagen, Hilden, Germany). Amplification of cDNA derived from 18s rRNA (for: 5'AAA CGG CTA CCA CAT CCA AG; rev: 5'-CCT CCA ATG GAT CCT CGT TA) was used for normalization.

\section{Quantification of NFKB activity}

Liver tissue extracts were obtained by homogenization of snap-frozen liver tissue in Cell Lysis Buffer from Cell Signaling (Danvers, MA, USA) supplemented with $1 \mathrm{mM}$ PMSF and a protease inhibitor cocktail (cOmplete Mini Protease Inhibitor Cocktail Tablets from Roche Diagnostics, Mannheim, Germany) using a MICCRA D1 homogenizer (ART Prozess- \& Labortechnik, Müllheim, Germany), and subsequent sonication (with a Sonopuls HD 70 from Bandelin electronics, Berlin, Germany) and centrifugation. Activated NFKB was quantified in liver tissue extracts via ELISA-technique using the PathScan Phospho-NFkB p65 (Ser536) Sandwich ELISA Antibody Pair from Cell Signaling following the manufacturer's protocols as described [6].

\section{Statistical analysis}

Values are presented as mean \pm SEM. Comparison between groups was made using the Mann Whitney test. A p value $<0.05$ was considered statistically significant. All calculations were performed using the statistical computer pack- 
age GraphPad Prism version 5.00 for Windows (GraphPad Software, San Diego, Ca, USA).

\section{Results \\ Effect of xanthohumol on hepatocellular dam- age in toxin induced liver injury}

To assess the effect of xanthohumol (XN) in the model of carbon tetrachloride $\left(\mathrm{CCl}_{4}\right)$ induced toxic liver injury mice were fed with control chow or a diet containing $0.5 \%(\mathrm{w} / \mathrm{w}) \mathrm{XN}$ resulting in a daily dose of approximately $1 \mathrm{mg} / \mathrm{g}$ body weight (BW). After 2 days of $\mathrm{XN}$-feeding, mice received a single dose of $\mathrm{CCl}_{4}(1 \mu \mathrm{l} / \mathrm{g} \mathrm{BW})$ or the same volume of the pure solvent (olive oil). Feeding of $\mathrm{XN}$ or control chow was continued, and 3 days after $\mathrm{CCl}_{4}$ application mice were sacrificed. At this time body weight did not differ significantly between control mice $(18.2 \pm 1.3 \mathrm{~g})$ and $\mathrm{XN}$-fed $(18.3 \pm 0.2 \mathrm{~g})$ animals, and mice receiving $\mathrm{CCl}_{4}$ alone $(16.4 \pm 1.3 \mathrm{~g})$ or $\mathrm{CCl}_{4}$ together with $\mathrm{XN}$ $(16.8 \pm 0.4 \mathrm{~g})$. However, liver weight and liver to body weight ratio, respectively, were significantly elevated in $\mathrm{CCl}_{4}$-treated mice but did not differ between $\mathrm{XN}$ - and control chow-fed mice (Figure 1A). Macroscopically, livers of $\mathrm{CCl}_{4}$ treated mice were larger and revealed a pale and irregular surface indicative of severe hepatocellular damage (Figure 1B). Histopathological analysis confirmed large areas of necrotic tissue in the central zones of the livers of $\mathrm{CCl}_{4}$-treated mice with no significant differences between the $\mathrm{XN}$-fed and control chow-fed group (Figure 1C). Hepatocellular damage in the $\mathrm{CCl}_{4}$ groups was also reflected by a marked increase of serum transaminases compared to both control groups, which was similar in $\mathrm{XN}$-fed and control chow-fed mice (Figure 1D and 1E).

\section{Effect of xanthohumol on hepatic inflammation and fibrosis in toxin induced liver injury}

To determine whether XN affects the inflammatory response after acute $\mathrm{CCl}_{4}$-mediated liver injury we analyzed the expression of proinflammatory cytokines in injured livers using semi-quantitative real-time PCR. $72 \mathrm{~h}$ after $\mathrm{CCl}_{4}$. injection, hepatic mRNA expression levels of tumor necrosis factor (TNF) and interleukin-1 alpha (IL-1 $\alpha$ ) were significantly elevated in mice without XN-feeding. In contrast, inflammatory gene expression was almost completely blunted in $\mathrm{CCl}_{4}$-treated mice by $\mathrm{XN}$-feeding (Figure $2 \mathrm{~A}$ and $2 \mathrm{~B}$ ). Similar results were obtained when analyzing hepatic mRNA expression of monocyte chemoattractant protein-1 (MCP-1) and intercellular adhesion molecule-1 (ICAM-1) (Figure 2C and 2D), both genes which are strongly regulated by the transcription factor NFKB. In line with these and previous in vitro findings by our group [6, 31] and others [3-6] we found $72 \mathrm{~h}$ after $\mathrm{CCl}_{4}$-injection significantly lower hepatic NFkB activity in $\mathrm{XN}$-fed mice compared to control chow-fed animals (Figure 2D).

Next, we determined if the reduced inflammation seen in $\mathrm{CCl}_{4}$-treated and $\mathrm{XN}$-fed mice is reflected by down-regulation of genes that mediate the fibrotic response. Levels of TGF- $\beta$ mRNA were markedly induced in control chow-fed $\mathrm{CCl}_{4}$ treated mice while in $\mathrm{XN}$-fed $\mathrm{CCl}_{4}$-treated mice expression levels of this cytokine, which plays a crucial pathophysiological role in liver fibrosis $[32,33]$, were not elevated compared to control mice (Figure $3 \mathrm{~A}$ ). In addition, expression of genes encoding collagen type I (Coll-I) and tissue inhibitor of matrix metalloproteinase-1 (TIMP-1) were induced after $\mathrm{CCl}_{4}$-treatment, but this increase was inhibited by $\mathrm{XN}$ application (Figure $3 \mathrm{~B}$ and $3 \mathrm{C}$ ). The expression of these genes reflects the onset of tissue remodeling processes, which can lead to fibrosis [34]. In line with this, a significant increase of alphasmooth muscle actin ( $\alpha$-SMA) expression was observable in control chow-fed but not in $\mathrm{XN}$-fed mice after $\mathrm{CCl}_{4}$-treatment, indicating a XNmediated inhibition of injury-triggered HSC activation (Figure 3D). These data indicate that livers of $\mathrm{XN}$-fed animals display a diminished proinflammatory and pro-fibrotic response after $\mathrm{CCl}_{4}$-induced injury.

\section{Discussion}

The aim of this study was to investigate the effect of xanthohumol (XN) in an acute model of liver injury and to further study its role in liver fibrosis. For this purpose we subjected mice fed with and without XN (at a dose of approximately $1 \mathrm{mg} / \mathrm{g}$ body weight) to acute $\mathrm{CCl}_{4}$-induced liver damage. Our results reveal a profound inhibitory effect of XN on pro-inflammatory and profibrogenic hepatic gene expression in this model. Noteworthy, these effects occurred despite the fact that hepatocellular injury as reflected by serum levels of transaminases or histomorphological analysis was comparable between control mice and XN-fed mice $72 \mathrm{~h}$ after $\mathrm{CCl}_{4}$-injection. These findings suggest that 
A

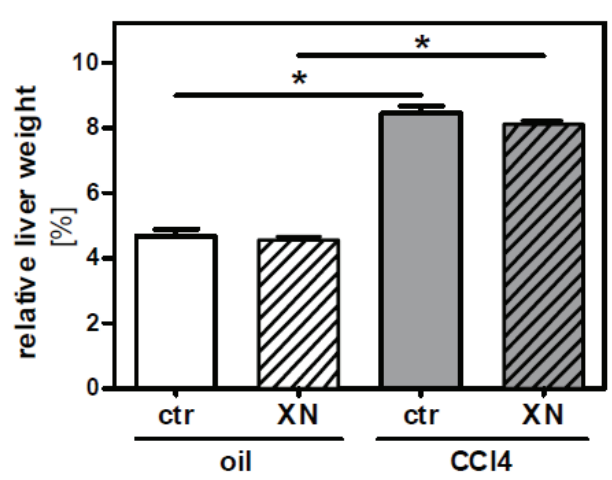

C

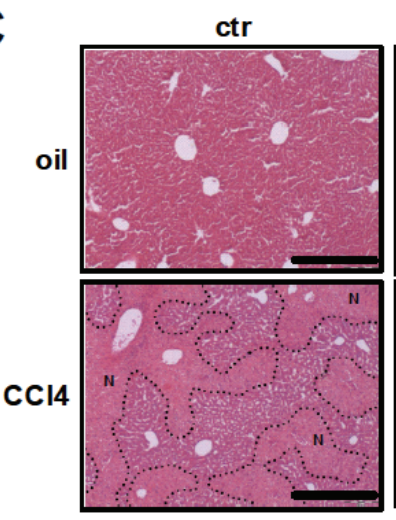

$\mathbf{E}$

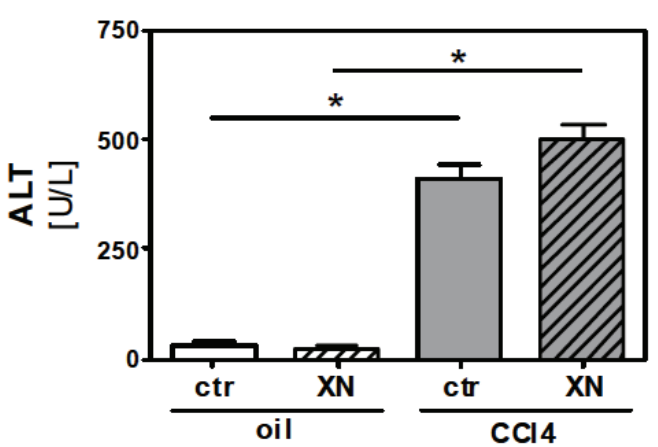

B

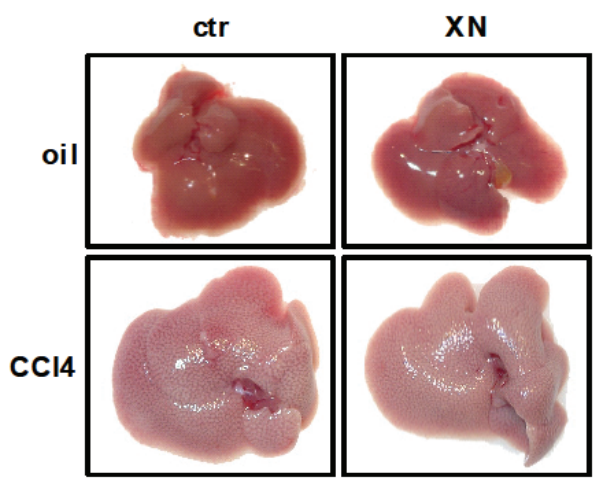

D

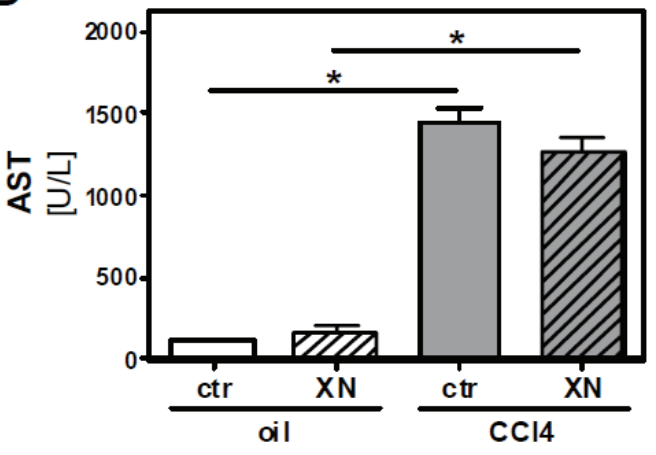

Figure 1. Effect of xanthohumol on hepatocellular damage in toxin induced liver injury. Mice were fed either with control chow (ctr.) or with the same chow supplemented with $0.5 \%(\mathrm{w} / \mathrm{w})$ xanthohumol (XN). After 2 days of feeding a single dose of $\mathrm{CCl}_{4}(1 \mu \mathrm{l} / \mathrm{g}$ body weight in olive oil) or olive oil alone (oil) was injected intraperitoneally to mice from both the control chow-fed and XN-fed group. $72 \mathrm{~h}$ after $\mathrm{CCl}_{4}$ or olive oil injection mice were sacrificed. (A) Liver-to-body -weight-ratio ( $*$ : $p<0.05)$. (B) Representative macroscopic images of livers from the four treatment groups. (C) HEstaining of liver tissue. Necrotic areas are marked out by dotted lines. Black bars represent $0.5 \mathrm{~mm}$. (D) AST and (E) ALT serum levels $(*: p<0.05)$.

the suppressive effect of $\mathrm{XN}$ against the progress of acute $\mathrm{CCl}_{4}$-induced hepatic fibrosis involves direct mechanisms related to its ability to block both hepatic inflammation and the activation of hepatic stellate cells (HSC). Actually, we have previously shown that $\mathrm{XN}$ exhibits direct anti-inflammatory effects on HSC and inhibits the activation of these cells, respectively, by inhibiting $\mathrm{I} K \mathrm{~B} \alpha$ degradation and subsequent NFkB activation [6]. Notably, these antifibrogenic effects have been observed at concentrations as low as $5 \mu \mathrm{M}$. Previous studies 
A

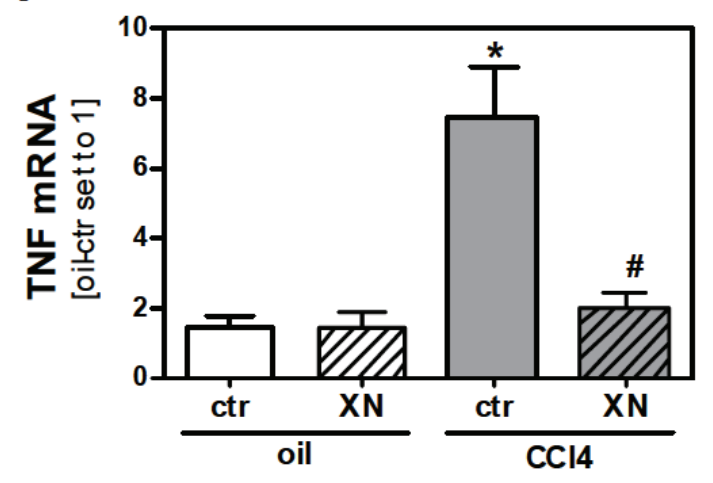

C

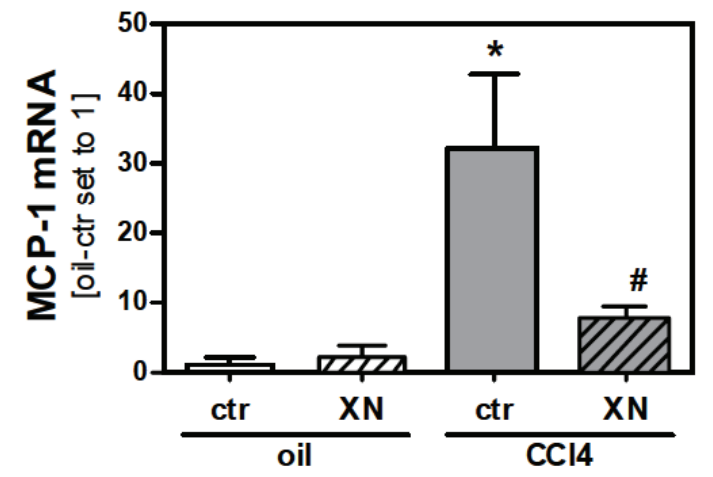

$\mathbf{E}$

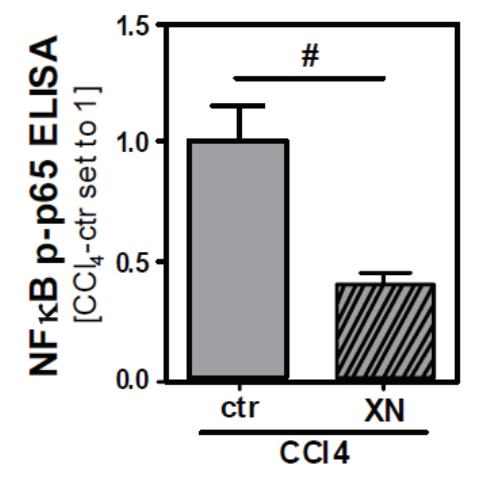

B

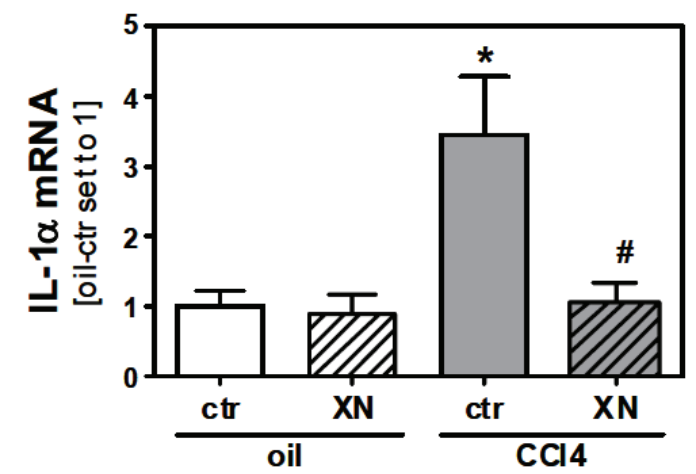

D

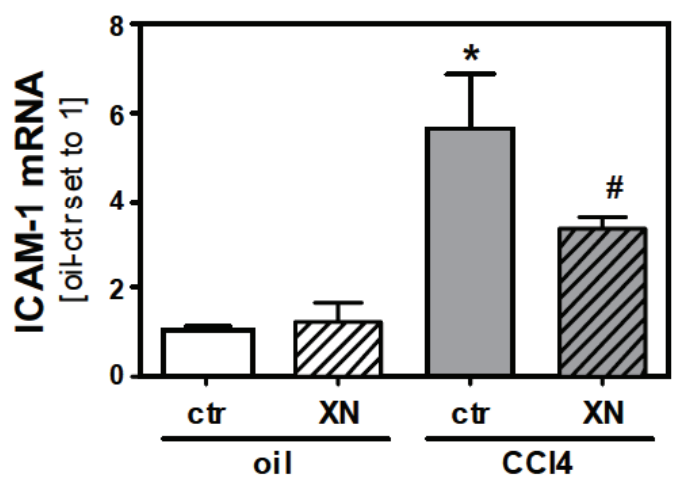

Figure 2. Effect of xanthohumol on hepatic inflammation in toxin induced liver injury. Mice were fed either with control chow (ctr) or with the same chow supplemented with $0.5 \%(\mathrm{w} / \mathrm{w})$ xanthohumol (XN). After 2 days of feeding a single dose of $\mathrm{CCl}_{4}(1 \mu \mathrm{l} / \mathrm{g}$ body weight in olive oil) or olive oil alone (oil) was injected intraperitoneally to mice from both the control chow-fed and $\mathrm{XN}$-fed group. $72 \mathrm{~h}$ after $\mathrm{CCl}_{4}$ or olive oil injection mice were sacrificed. Analysis of hepatic mRNA levels of (A) TNF, (B) IL-1 $\alpha,(C)$ MCP-1 and (D) ICAM-1 by quantitative RT-PCR (*: $p<0.05$ compared to oil-ctr; \#: $\mathrm{p}<0.05$ compared to $\mathrm{CCl}_{4}$-ctr). (E) Comparison of NFkB activity in livers of control chow-fed and XN-fed mice $72 \mathrm{~h}$ after $\mathrm{CCl}_{4}$-injection via ELISA-based quantification of phospho-p65 (Ser536) (*: p<0.05).

could not detect (unmetabolized and unconjugated) $\mathrm{XN}$ in the systemic circulation upon oral application [35, 36]. However, the anatomical situation of the liver has to be considered. It can be expected that after oral intake the XN concentration in the portal vein is higher than in the systemic circulation. Further, HSC are located in the liver in the space of Disse (or perisinusoidal 
A

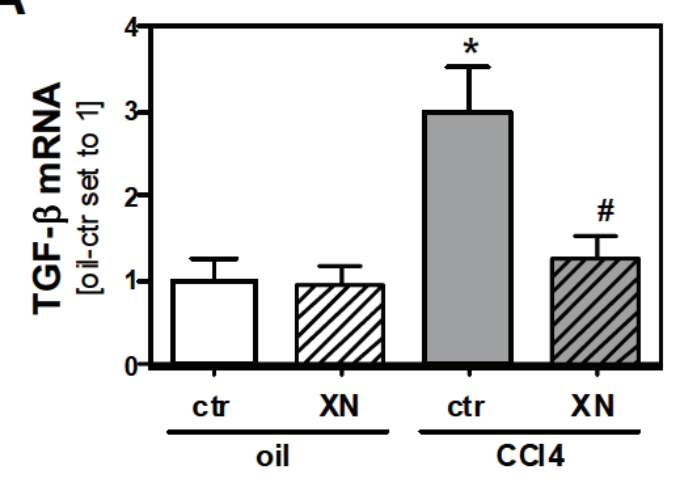

C

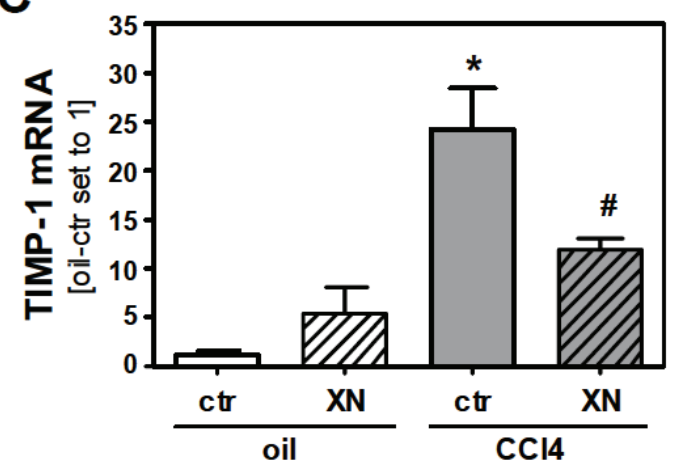

B

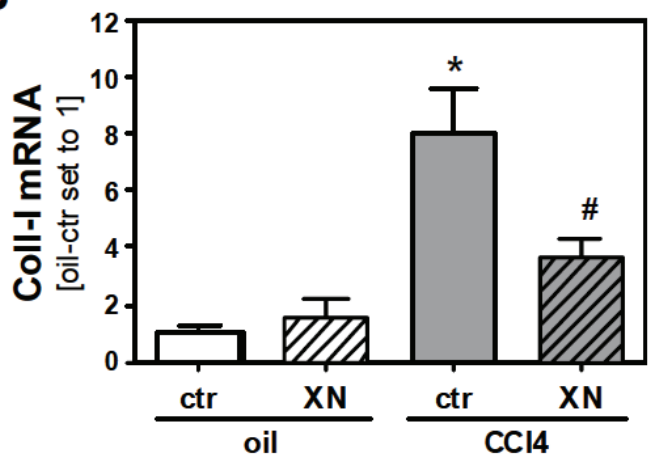

D

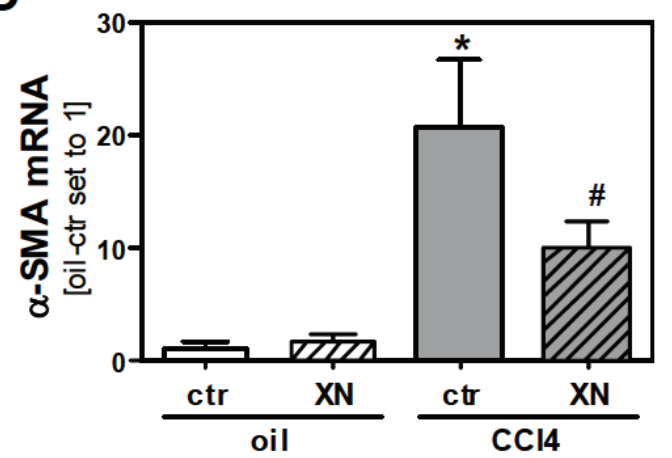

Figure 3. Effect of xanthohumol on toxin induced fibrogenic response of the liver. Mice were fed either with control chow (ctr) or with the same chow supplemented with $0.5 \%(\mathrm{w} / \mathrm{w})$ xanthohumol (XN). After 2 days of feeding a single dose of $\mathrm{CCl}_{4}(1 \mu \mathrm{l} / \mathrm{g}$ body weight in olive oil) or olive oil alone (oil) was injected intraperitoneally to mice from both the control chow-fed and $\mathrm{XN}$-fed group. $72 \mathrm{~h}$ after $\mathrm{CCl}_{4}$ or olive oil injection mice were sacrificed. Analysis of hepatic mRNA levels of (A) TGF- $\beta$, (B) Coll-I, (C) TIMP-1 and (D) $\alpha$-SMA by quantitative RT-PCR (*: $p<0.05$ compared to oil-ctr; $\#: \mathrm{p}<0.05$ compared to $\mathrm{CCl}_{4}$-ctr).

space), i.e. between the sinusoid and the hepatocytes. Herewith, HSC are directly exposed to $\mathrm{XN}$ concentration reaching the liver via the portal vein irrespective of (subsequent) metabolism in hepatocytes. Thus, XN concentrations reaching HSC in the space of Disse may be significantly higher than the levels in whole liver tissue.

In our previous study we have shown that XN inhibits hepatic inflammation and fibrosis in mice in a NASH model [6]. In this model hepatocellular lipid accumulation led to a mild inflammation and fibrogenic response after 3 weeks of feeding a NASH inducing diet. In contrast, the $\mathrm{CCl}_{4}$-model is used to induce extended hepatocellular death and inflammation, which in turn promotes fibrosis. The marked anti-fibrogenic effect of XN under these acute and harsh ex- perimental conditions further advances the concept that $\mathrm{XN}$ is a promising natural substance with the potential to inhibit the development and progression of hepatic fibrosis in patients with (chronic) liver disease.

\section{Acknowledgements}

We want to thank Ruth Schewior and Marina Fink for excellent technical assistance. This work was supported by grants from the German Research Association (He 2458/14-1 to C.H.) and the Medical Faculty of the University of Regensburg (ReForM) to C.H. Further, this project was supported in part by an unrestricted research grant from the Joh. Barth \& Sohn GmbH (Nuremberg, Germany). Financial relationships of the authors with Joh. Barth \& Sohn GmbH are as follows: C.H. is a consultant, and C.D. is work- 


\section{Xanthohumol effects in toxic liver injury}

ing in the laboratory of C.H. All authors had complete and independent control over the study design, analysis and interpretation of data, report writing, and publication, regardless of results.

Address correspondence to: Dr. Claus Hellerbrand, Dept. of Internal Medicine I, University Hospital Regensburg, D-93053 Regensburg, Germany Tel: +49941-944-7155; Fax: +49-941-944-7154; E-mail: claus.hellerbrand@klinik.uni-regensburg.de

\section{References}

[1] Zanoli P, Zavatti M. Pharmacognostic and pharmacological profile of Humulus lupulus L. J Ethnopharmacol 2008; 116: 383-396.

[2] Stevens JF, Page JE. Xanthohumol and related prenylflavonoids from hops and beer: to your good health! Phytochemistry 2004; 65: 13171330.

[3] Albini A, Dell'Eva R, Vene R, Ferrari N, Buhler DR, Noonan DM and Fassina G. Mechanisms of the antiangiogenic activity by the hop flavonoid xanthohumol: NF-kB and Akt as targets. FASEB J 2006; 20: 527-529.

[4] Dell'Eva R, Ambrosini C, Vannini N, Piaggio G, Albini $A$ and Ferrari N. AKT/NF-KB inhibitor xanthohumol targets cell growth and angiogenesis in hematologic malignancies. Cancer 2007; 110: 2007-2011.

[5] Harikumar KB, Kunnumakkara AB, Ahn KS, Anand P, Krishnan S, Guha S and Aggarwal BB. Modification of the cysteine residues in $1 \kappa B \alpha$ kinase and NF-kB (p65) by xanthohumol leads to suppression of NF-KB-regulated gene products and potentiation of apoptosis in leukemia cells. Blood 2009; 113: 2003-2013.

[6] Dorn C, Kraus B, Motyl M, Weiss TS, Gehrig M, Scholmerich J, Heilmann J and Hellerbrand C. Xanthohumol, a chalcon derived from hops, inhibits hepatic inflammation and fibrosis. Mol Nutr Food Res 2010; 54: S205-213.

[7] Cobbold JF, Anstee QM and Taylor-Robinson SD. The importance of fatty liver disease in clinical practice. Proc Nutr Soc 2010; 69: 518527.

[8] Clark JM, Brancati FL and Diehl AM. Nonalcoholic fatty liver disease. Gastroenterology 2002; 122: 1649-1657.

[9] Vernon G, Baranova A and Younossi ZM. Systematic review: the epidemiology and natural history of non-alcoholic fatty liver disease and non-alcoholic steatohepatitis in adults. Aliment Pharmacol Ther 2011; 34: 274-285.

[10] Tannapfel A, Denk H, Dienes HP, Langner C, Schirmacher P, Trauner M and Flott-Rahmel B. Histopathological diagnosis of non-alcoholic and alcoholic fatty liver disease. Virchows Arch 2011; 458: 511-523.

[11] Gines P, Cardenas A, Arroyo V and Rodes J.
Management of cirrhosis and ascites. N Engl J Med 2004; 350: 1646-1654.

[12] Minguez B, Tovar V, Chiang D, Villanueva A and Llovet JM. Pathogenesis of hepatocellular carcinoma and molecular therapies. Curr Opin Gastroenterol 2009; 25: 186-194.

[13] Villanueva A, Newell P, Chiang DY, Friedman SL and Llovet JM. Genomics and signaling pathways in hepatocellular carcinoma. Semin Liver Dis 2007; 27: 55-76.

[14] Cutroneo KR. How is Type I procollagen synthesis regulated at the gene level during tissue fibrosis. J Cell Biochem 2003; 90: 1-5.

[15] Lang A, Brenner DA. Gene regulation in hepatic stellate cell. Ital J Gastroenterol Hepatol 1999; 31: 173-179.

[16] Brenner DA, Waterboer T, Choi SK, Lindquist JN, Stefanovic B, Burchardt E, Yamauchi M, Gillan A and Rippe RA. New aspects of hepatic fibrosis. J Hepatol 2000; 32: 32-38.

[17] Kisseleva T, Brenner DA. Role of hepatic stellate cells in fibrogenesis and the reversal of fibrosis. J Gastroenterol Hepatol 2007; 22: S73 $-78$.

[18] Maher JJ, Bissell DM. Cell-matrix interactions in liver. Semin Cell Biol 1993; 4: 189-201.

[19] Hautekeete ML, Geerts A. The hepatic stellate (Ito) cell: its role in human liver disease. Virchows Arch 1997; 430: 195-207.

[20] Lee KS, Buck M, Houglum K and Chojkier M. Activation of hepatic stellate cells by TGF $\alpha$ and collagen type I is mediated by oxidative stress through c-myb expression. J Clin Invest 1995; 96: 2461-2468.

[21] Lang A, Schoonhoven R, Tuvia S, Brenner DA and Rippe RA. Nuclear factor $k B$ in proliferation, activation, and apoptosis in rat hepatic stellate cells. J Hepatol 2000; 33: 49-58.

[22] Hellerbrand C, Jobin C, limuro Y, Licato L, Sartor RB and Brenner DA. Inhibition of NFKB in activated rat hepatic stellate cells by proteasome inhibitors and an IkB super-repressor. Hepatology 1998; 27: 1285-1295.

[23] Grunhage F, Fischer HP, Sauerbruch $T$ and Reichel C. Drug- and toxin-induced hepatotoxicity. Z Gastroenterol 2003; 41: 565-578.

[24] Zimmerman HJ, Lewis JH. Chemical- and toxininduced hepatotoxicity. Gastroenterol Clin North Am 1995; 24: 1027-1045.

[25] Mehendale HM, Roth RA, Gandolfi AJ, Klaunig JE, Lemasters JJ and Curtis LR. Novel mechanisms in chemically induced hepatotoxicity. FASEB J 1994; 8: 1285-1295.

[26] Huh CG, Factor VM, Sanchez A, Uchida K, Conner EA and Thorgeirsson SS. Hepatocyte growth factor/c-met signaling pathway is required for efficient liver regeneration and repair. Proc Natl Acad Sci USA 2004; 101: 4477-4482.

[27] Iredale JP. Models of liver fibrosis: exploring the dynamic nature of inflammation and repair in a solid organ. J Clin Invest 2007; 117: 539-548.

[28] Gabele E, Muhlbauer M, Dorn C, Weiss TS, Froh 


\section{Xanthohumol effects in toxic liver injury}

M, Schnabl B, Wiest R, Scholmerich J, Obermeier $F$ and Hellerbrand C. Role of TLR9 in hepatic stellate cells and experimental liver fibrosis. Biochem Biophys Res Commun 2008; 376: 271-276.

[29] Hellerbrand C, Muhlbauer M, Wallner S, Schuierer M, Behrmann I, Bataille F, Weiss T, Scholmerich J and Bosserhoff AK. Promoterhypermethylation is causing functional relevant downregulation of methylthioadenosine phosphorylase (MTAP) expression in hepatocellular carcinoma. Carcinogenesis 2006; 27: 64-72.

[30] Muhlbauer M, Bosserhoff AK, Hartmann A, Thasler WE, Weiss TS, Herfarth H, Lock G, Scholmerich J and Hellerbrand C. A novel MCP1 gene polymorphism is associated with hepatic MCP-1 expression and severity of HCVrelated liver disease. Gastroenterology 2003; 125: 1085-1093.

[31] Dorn C, Weiss TS, Heilmann J and Hellerbrand C. Xanthohumol, a prenylated chalcone derived from hops, inhibits proliferation, migration and interleukin-8 expression of hepatocellular carcinoma cells. Int J Oncol 2010; 36: 435-441.

[32] Gressner AM, Weiskirchen R. Modern pathogenetic concepts of liver fibrosis suggest stellate cells and TGF- $\beta$ as major players and therapeutic targets. J Cell Mol Med 2006; 10: 76-99.
[33] Brenner DA. Molecular pathogenesis of liver fibrosis. Trans Am Clin Climatol Assoc 2009; 120: 61-368.

[34] Iredale JP, Benyon RC, Arthur MJ, Ferris WF, Alcolado R, Winwood PJ, Clark N and Murphy G. Tissue inhibitor of metalloproteinase-1 messenger RNA expression is enhanced relative to interstitial collagenase messenger RNA in experimental liver injury and fibrosis. Hepatology 1996; 24: 176-184.

[35] Avula B, Ganzera M, Warnick JE, Feltenstein MW, Sufka KJ and Khan IA. High-performance liquid chromatographic determination of xanthohumol in rat plasma, urine, and fecal samples. J Chromatogr Sci 2004; 42: 378-382.

[36] Bolca S, Li J, Nikolic D, Roche N, Blondeel P, Possemiers S, De KD, Bracke M, Heyerick A, van Breemen RB and Depypere H. Disposition of hop prenylflavonoids in human breast tissue. Mol Nutr Food Res 2010; 54: S284-294. 